\title{
IMPLEMENTASI MODIFIKASI PEMBELAJARAN DAN SIMPLE FEEDBACK DALAM PEMBELAJARAN AKTIVITAS PERMAINAN BOLA VOLI UNTUK MENINGKATKAN WAKTU AKTIF BELAJAR
}

\author{
Hamdi $^{1)}$, Suherman Slamet ${ }^{1)}$ \\ ${ }^{1}$ Fakultas Pendidikan Olahraga dan Kesehatan, Universitas Pendidikan Indonesia \\ email: suhermanslamet@upi.edu
}

\begin{abstract}
Tujuan penelitian ini untuk mengetahui apakah terdapat pengaruh yang signifikan dari penerapan modifikasi pembelajaran dan penerapan simple feedback dapat memberikan hasil yang signifikan terhadap waktu aktif belajar siswa dalam melakukan gerakan permainan bola voli di kelas XI SMA Kartika XIX-2 Bandung.Instrument yang digunakan dalam penelitian tindakan kelas ini menggunakan observasi waktu aktif belajar.Metode penelitian yang digunakan adalah penelitian tindakan kelas atau classroom action research.Dalam penggunaan metode ini peneliti menggunakan dua siklus.Dalam setiap siklusnya terdiri dari dua tindakan.Selanjutnya untuk variabel bebas adalah penerapan modifikasi pembelajaran dan penerapan simple feedback dan variable terikatnya adalah waktu aktif belajar siswa dalam melakukan gerakan permainan bola voli di kelas XI SMA Kartika XIX-2 Bandung.Untuk populasi dalam penelitian ini adalah siswa-siswi kelas XIIPS-2.Dari analisis data didapat data Tindakan satu sebanyak $8.75 \%$, Tindakan dua meningkat menjadi $26.3 \%$. Tindakan tiga meningkat hingga 47.2\%, Dari Tindakan empat meningkat $73 \%$ Dari hasil penelitian ini dapat disimpulkan bahwa dengan adanya penerapan modifikasi pembelajaran dan penerapan simple feedback dapat memberikan hasil yang signifikan terhadap waktu aktif belajar dalam melakukan gerakan permainan bola voli di kelas X SMA Kartika XIX-2 Bandung.
\end{abstract}

Keywords: modifikasi, pembelajaran, simple feedback, waktu aktif belajar

\section{PENDAHULUAN}

Pendidikan jasmani merupakan salah satu mata pelajaran yang diterapkan di sekolah. Pendidikan jasmani menekankan pada suatu proses seseorang sebagai individu maupun anggota masyarakat yang dilakukan secara sadar dan sistematik melalui berbagai kegiatan dalam rangka memperoleh kemampuan dan keterampilan jasmani, pertumbuhan, kecerdasan, dan pembentukan watak. Pada hakikatnya kita ketahui bersama pendidikan jasmani adalah proses pendidikan yang memanfaatkan aktivitas fisik untuk menghasilkan perubahan progresif dalam kualitas individu, baik dalam hal fisik, mental, serta emosional. Tujuan pendidikan jasmani di sekolah selalu mencakup tiga aspek kognitif, aspek afektif dan aspek psikomotor. Hal ini sesuai dengan yang dikemukakan oleh Juliantine (2012, hlm 7) mengatakan bahwa:

Pendidikan jasmani adalah untuk mengembangkan individu menjadi individuindividu yang kreatif, berdaya cipta, dan yang dapat menemukan atau discover. Serta pendidikan sebagai proses menolong, membimbing, mengarahkan dan mendorong individu 
Berdasarkan pemaparan teori di atas, kita dapat memandang bahwa pendidikan jasmani merupakan bagian integral dari proses pendidikan secara keseluruhan, tujuan pendidikan jasmani selaras dengan tujuan yang ingin dicapai dalam dunia pendidikan di Indonesia hal ini sejalan dengan UU nomor 2 tahun 2003 tentang sistem pendidikan nasional yang menegaskan bahwa pendidikan nasional sebagai system suatu kesatuan yang utuh dan terpadu dari semua kesatuan dan kegiatan pendidikan. Terdapat tiga ranah yang menjadi tujuan pendidikan jasmani yaitu kognitif, apektif, dan psikomotor.

Pendidikan jasmani olahraga dan kesehatan merupakan mata pelajaran yang tak dapat dipisahkan dengan kurikulum, yang bertujuan agar siswa menjadi terampil dalam melakukan aktifitas fisik dan meningkatkan kesegaran jasmani siswa. Karena melalui pendidikan jasmani olahraga dan kesehatan, peserta didik dapat mengembangkan kemampuan gerak dasar yang mendukung sikap (afektif) dan perilaku (behavioral) hidup bersih dan gerak (psikomotorik) serta kesegaran jasmani. Hal ini sejalan dengan pendapat para ahli mengenai pengertian pendidikan yang dikemukakan oleh jhon dewey dalam Lutan (2008, hlm. 95) mengatakan bahwa:

Dalam kehidupan, pendidikan mempunyai andil besar. Definisi pendidikan sebagai rekontruksi aneka pengalaman dan peristiwa yang dialami dalam kehidupan individu sehingga segala sesuatu yang baru menjadi lebih terarah dan bermakna

Pendidikan jasmani olahraga dan kesehatan disesuaikan dengan keadaan dan kebutuhan lingkungan, sehingga materi pelajaran pendidikan jasmani olahraga dan kesehatan khususnya di SMA menekankan pada aktivitas jasmani dalam rangka pembentukan kebiasaan hidup sehat serta membantu peserta didik mencapai pertumbuhan ke arah yang optimal.

Pada pembahasan di atas, kita dapat mengambil kesimpulan bahwa pendidikan jasmani hakikatnya adalah pendidikan yang berjalan melalui aktifitas jasmani atau aktifitas gerak. Pendidikan jasmani diajarkan di sekolah dengantujuan untuk meningkatkan kemampuan kognitif, afektif dan psikomotor dan sebagai alat untuk mencapai tujuan pendidikan.

Berdasarkan dari hasil observasi peneliti di lapangan ketika praktek pengalaman lapangan di SMA Kartika XIX-2 Bandung. Berkaitan dengan pelaksanaan pembelajaran materi permainan bola voli, ditemukan oleh peneliti dimana guru terkesan hanya memberi sekedar tugas dan siswa melakukan apa yang ditugaskan. Hal itu mengesankan pemahaman guru bahwa yang terpenting adalah siswa dapat aktif dan gerak sedangkan urusan tahapan belajarnya tidak dalam prioritas utama.

Dalam pelaksanaan belajar mengajar di lapangan, ketika siswa melakukan kegiatan pembelajaran bola voli, guru tidak memberikan koreksi atau teguran pada siswa yang enggan melakukan atau kesiapan belajar siswa rendah. Di luar situasi itu, ternyata siswapun tidak memahami mana gerakan yang salah dan mana gerakan passing yang benar. Seperti halnya ketika siswa melakukan pembelajaran permainan bola voli, karena akibat lutut kurang merendah siswa sering kali gagal. Permasalahan yang terjadi di lapangan ini disikapi oleh guru tersebut tanpa ada teguran atau koreksi secara personal kepada siswa. Sehingga akibatnya siswa tidak konsentrasi dalam mengkuti pembelajaran..

Hal ini terus berlangsung hingga mengakibatkan siswa tidak bisa memperagakan gerakan dalam permainan bola voli. Padahal jika melihat jumlah pertemuan hanya diberikan dua pertemuan untuk permainan bola besar seperti bola voli ini. Begitu juga dengan waktu yang diberikan hanya 3 x 45 menit tiap pertemuan. Waktu singkat itu menekan guru agar lebih kreatif dan inovatif dalam merancang pembelajaran yang paikem. 
Salah satu upaya untuk menciptakan kegiatan belajar yang efektif sesuai dengan kondisi lapangan saat ini menurut peneliti adalah dengan adanya simple feedback dan modifikasi pembelajaran permainan bola voli. Hal ini dilakukan karena berdasarkan hasil observasi di lapangan, guru kurang memberikan perhatian yang lebih pada siswa. Berkaitan dengan hal itu, dengan adanya simple feedback inilah bisa menjadikan pembelajaran lebih efektif meningkatkan waktu aktif belajar permainan bola voli di SMA Kartika XIX-2 Bandung.

Secara umum simple feedback ini menurut Adang Suherman (2009, hlm 145) adalah umpan balik yang hanya terfokus pada satu komponen keterampilan dalam satu saat. Simple feedback sering berisikan satu atau dua buah kata kunci (key words) yang menggambarkan aktivitas penyempurnaan (clue) dan diulang-ulang sebagai feedbackselama PBM berlangsung.

Dengan adanya simple feedback ini diharapakan dapat membantu peningkatan waktu aktif belajar. Dimana siswa dapat memahami kesalahan dan apa yang harus diperbuat dari koreksi guru secara personal.Selanjutnya upaya kedua yang dilakukan oleh peneliti adalah dengan memodifikasi pembelajaran permainan bola voli.Kita ketahui bersama bahwa tujuan dari modifikasi pembelajaran pendidikan jasmani tentunya untuk membantu, mempermudah siswa dalam melaksanakan pembelajaran jasmani. Dalam kesempatan ini peneliti akan menerapkan modifikasi pada pembelajaran permainan bola voli. pembelajaran yang peneliti modifikasi adalah dengan cara bermain satu lawan satu, dua lawan dua dan seterusnya. Hal di atas peneliti modifikasi dengan maksud tujuan untuk mempermudah belajar siswa dalam aktivtas permainan bola voli dengan tahapan belajar dengan tingkat kemampuan siswa.

Melihat dari dua upaya yang peneliti terapkan dapat memberikan dampak dari masalah kurangnya waktu aktif belajar siswa dalam permainan bola voli di sekolah.Dari kurangnya waktu belajar inilah yang mengakibatkan penurunan kualitas siswa dalam belajar. Dengan demikian peneliti akan mengambil judul: "Implementasi Modifikasi Pembelajaran Dan Simple FeedbackDalam Pembelajaran Aktivitas Permainan Bola VoliUntuk Meningkatkan Waktu Aktif Belajar. (Penelitian Tindakan Kelas Di Kelas XI Di SMA Kartika XIX-2 Bandung)".

\section{METODE PENELITIAN}

Metode yang digunakan dalam penelitian ini adalah metode penelitian tindakan kelas (PTK) atau class room action research.sebagai cara untuk menjawab permasalahan yang ada. yaitu suatu pencermatan terhadap kegiatan belajar berupa sebuah tindakan yang sengaja dimunculkan dan terjadi dalam sebuah kelas secara bersama (Arikunto, 2008:3). Penelitian tindakan kelas merupakan suatu bentuk penelitian reflektif dengan melakukan tindakan-tindakan tertentu agar dapat memperbaiki dan meningkatkan praktik pembelajaran di kelas secara profesional. Hal ini sesuai dengan pendapat Subroto (2014, hlm. 6 mengemukakan bahwa:

Penelitian tindakan merupakan salah satu cara strategis dalam memperbaiki dan meningkatkan layanan pendidikan yang harus dilaksanakan dalam konteks pembelajaran dan atau dalam peningkatan kualitas program sekolah secara keseluruhan.

Berdasarkan uraian di atas, bahwa yang dimaksud dengan penelitian tindakan kelas merupakan suatu penelitian yang dilakukan oleh guru sekaligus sebagai peneliti, dari penyusunan suatu perencanaan pembelajaran sampai tindakan penelitian di dalam kelas yang berupa kegiatan belajar yang bertujuan untuk memperbaiki proses belajar mengajar yang akan dilakukan oleh pendidik (guru). 
Alasan digunakan metode penelitian tindakan kelas ini disebabkan oleh keinginan peneliti menanggulangi atau memperbaiki proses pembelajaranpenjas di kelas XI-IPS-2 SMA Kartika XIX-2 Bandung.Melalui penelitian ini peneliti dapat langsung mendeteksi dan memecahkan masalah waktua aktif belajaar yang dihadapi para peserta didik dalam pembelajaran permainan bola voli.

\subsection{Populasi Dan Sampel}

Dapat disimpulkan bahwa populasi merupakan sekumpulan objek yang memiliki karakteristik tertentu. Adapun yang dijadikan populasi dalam penelitian ini adalah di Kelas XI-IPS-2 SMA Kartika XIX-2 Bandung.Sampel merupakan sebagian atau wakil dari populasi yang diteliti.Menurut Sugyono (2011, hlm. 81) mengatakan juga sampel adalah "Bagian dari jumlah dan karakteristik yang dimiliki oleh populasi tersebut".Dari pengertian diatas dapat disimpulkan bahwa sampel adalah wakil dari populasi yang diambil datanya dan kemudian data tersebut diolah dan diteliti.Adapun yang menjadi sampel dari penelitian ini adalah siswa-siswi kelas XI-IPS-2 SMA Kartika XIX-2 Bandung.

\subsection{Instrument}

Menggunakan observasi berupa lembaran untuk menilai waktu aktif belajar siswa dalam pembelajaran aktivitas siswa dalam permainan bola voli.Observasi ini dilakukan ketika dalam melakukan pembelajaran dilaksanakan.

\section{HASIL DAN PEMBAHASAN}

Hasil analisis yang ditemukan bahwasanya adanya koreksi secara langsung ini memberikan dorongan pada siswa untuk aktif melakukan pembelajaran bola voli dengan baik.Dalam proses penelitian, penelitian ini dilakukan dua siklus. Dimana dalam satu siklus terdapat dua tindakan. Berikut peneliti paparkn hasil dari lapangan terkait mengenai waktu aktif belajar siswa dalam permainan bola bola voli kelas XI di SMAKartikaXIX-2Bandung.

Tabel. 4.1 Ringkasan Hasil Penelitian Waktu Aktif Belajar Siswa kelas XI di SMAKartikaXIX-2 Bandung

\begin{tabular}{|c|c|c|c|c|c|}
\hline \multirow{2}{*}{ Hasil } & \multirow{2}{*}{$\begin{array}{l}\text { Data } \\
\text { Awal }\end{array}$} & \multicolumn{2}{|c|}{ Siklus 1} & \multicolumn{2}{|c|}{ Siklus 2} \\
\hline & & T1 & T2 & T3 & T 4 \\
\hline Jumlah & 216 & 235 & 273 & 318 & 374 \\
\hline $\mathbf{X}$ & 7,2 & $\begin{array}{r}7,8 \\
33\end{array}$ & 9,1 & 10.6 & 12.46 \\
\hline
\end{tabular}

Dari hasil di atas, peneliti dapat mengambil kesimpulan bahwa adanya peningkatan dari waktu aktif belajar siswa dalam permainan bola voli di SMAKartikaXIX-2 Bandung. hal ini terlihat dari nilai setiap tindakan yang terus meningkat. Berikut hasil penelitian waktu aktif belajar siswa dalam permainan bola voli di SMAKartikaXIX-2 Bandung. dalam diagram ini terlihat adanya perkembangan yang meningkat dari keaktifan belajar siswa.

Diperoleh hitungan persentasi penelitian sebagai berikut:

a. DA-T1

$$
D A-T 1=\frac{7.83-7.2}{7.2} \times 100 \%=8.75 \%
$$


b. DA-T2

$D A-T 2=\frac{9.1-7.2}{7.2} 100 \%=26.3 \%$

c. DA-T3

$D A-T 3=\frac{10.6-7.2}{7.2} \times 100 \%=47.2 \%$

d. DA-T4

$D A-T 4=\frac{12.46-7.2}{7.2} \times 100 \%=73 \%$

e. T1-T2

$T 1-T 2=\frac{9.1-7.83}{7.83} X 100 \%=16.21 \%$

f. T2-T3

$T 2-T 3=\frac{10.6-9.1}{9.1} \times 100 \%=16.48$

\section{g. T3-T4}

$$
T 3-T 4=\frac{12.46-10.6}{10.6} \times 100 \%=17.54 \%
$$

\section{h. T1-T3}

$T 1-T 3=\frac{10.6-7.83}{7.83} X 100 \%=35.37 \%$

i. T1-T4

$T 1-T 4=\frac{12.46-7.83}{7.83} X 100 \%=59.13 \%$

j. T2-T4

$$
T 2-T 4=\frac{12.46-9.1}{9.1} X 100 \%=36.92 \%
$$

Dari pembahasan di atas, didapatdari perjalanan siklus satu hingga siklus dua. Dimana setiap siklusnya diterapkan dua tindakan, bahwa dapat disimpulkan peserta didik mengalami tingkat waktu belajar yang baik dalam permainan bola voli. dari analisis data didapat data awal ke tindakan satu sebanyak $8.75 \%$. Tindakan dua meningkat menjadi $16.21 \%$. Tindakan tiga meningkat hingga $16.48 \%$. Dari Tindakan empat meningkat $17.54 \%$. Jika di simpulkan secara keseluruhan dari data awal hingga pada akhir tindakan terjadi peningkatan.

\section{KESIMPULAN}

Bermula dari permasalahan hasil observasi lapangan, ketika praktek pengalaman lapangan di SMA Kartika XIX-2 Bandung. pelaksanaan pembelajaran materi permainan bola voli, ditemukan oleh peneliti dimana guru terkesan hanya memberi sekedar tugas dan siswa melakukan apa yang ditugaskan. Hal itu mengesankan pemahaman guru bahwa yang terpenting adalah siswa dapat aktif dan gerak sedangkan urusan tahapan belajarnya tidak dalam prioritas utama.

Dalam pelaksanaan belajar mengajar di lapangan, ketika siswa melakukan kegiatan pembelajaran bola voli, guru tidak memberikan koreksi atau teguran pada siswa yang enggan melakukan atau kesiapan belajar siswa rendah. Di luar situasi itu, ternyata siswapun tidak memahami mana gerakan yang salah dan mana gerakan passing yang benar. Seperti halnya ketika siswa melakukan pembelajaran permainan bola voli, karena akibat lutut kurang merendah siswa sering kali gagal. Permasalahan yang terjadi di lapangan ini disikapi oleh guru tersebut tanpa ada teguran atau koreksi secara personal kepada siswa. Sehingga akibatnya siswa tidak efektif dalam mengkuti pembelajaran. 
Alhasil dalam penelitian ini didapat dari perjalanan siklus satu hingga siklus dua. Dimana setiap siklusnya diterapkan dua tindakan, bahwa dapat disimpulkan peserta didik mengalami tingkat waktu belajar yang baik dalam permainan bola kasti. dari analisis data didapat data awal ke tindakan satu sebanyak 9,69\%. Dari tindakan satu ke tindakan dua meningkat menjadi $16,50 \%$. Dari tindakan dua ke tindakan tiga meningkat hingga 40,48\%. Dari tindakan tiga menuju tindakan empat meningkat $16,51 \%$. Jika di simpulkan secara keseluruhan dari data awal hingga pada akhir tindakan terjadi meningkatan sebanyak $79,55 \%$. 


\section{REFERENSI}

Abduljabar, B. Darajat. J.K.N. (2010). Modul Aplikasi Statistik dalam Penjas. Bandung: FPOK UPI

Arikunto, Suharsimi. (2002). Prosedur Penelitian Suatu Pendekatan Praktek Jakarta. Rineka Cipta.

Bahagia, Yoyo. (2010) Modul Modifikasi Pembelajaran Pendidikan Jasmani. Bandung: FPOK UPI.

Dimyati dan Mudjiono. (2006). Belajar dan pembelajaran.Jakarta. PT Rineka Cipta.

Suherman Adang. (2000). Prinsip Prinsip Pengembangan dan Modifikasi Cabang Olahraga. Departemen Pendidikan Nasional. Direktorat Jendral Pendidikan Sekolah

Suherman Adang. (2009). Revitalisasi Pengajaran Dalam Pendidikan Jasmani, Bandung : CV. Bintang WarliArtika

Juliantine, Yudiana, Y. Dkk. (2012). Belajar \& pembelajaran penjas. Bandung : Redpoint. Juliantine, Tite. (2012) Belajar dan Pembelajaran Penjas. Bandung: FPOK UPI.

Lutan, R. (2001).Belajar Keterampilan Motorik, Pengantar Teori dan Metode. Jakarta: P2LPTK Depdikbud RI

Mahendra, Agus. (2007). Teori belajar dan Pembelajaran Motorik.Jakarta Depdikbud: Tenaga Kependidikan.

Subroto, Toto (2014) Penulisan Penelitian Tindakan Kelas. Bandung: FPOK UPI

Subroto Toto dan Yudiana Yunyun. (2010). Permainan Bola Voli. UniversitasPendidikan Indonesia. Bandung

Sudjana, (2009). Metode Statistik. Jakarta : Rineka Cipta.

Sugiyono. (2011). Metode Penelitian Pendidikan: pendekatan kuantitatif, kualitatif, dan $R \& D$. Bandung: Alfabeta.

Sukmadinata, Nana Syaodih. (2004).Kurikulum dan Pembelajaran Kompetensi. Bandung: Kesuma Karya. 